\title{
Seasonal variability of meridional temperature fluxes in the eastern North Atlantic Ocean
}

\author{
by Lothar Stramma' and Hans-Jörg Isemer ${ }^{1,2}$
}

\begin{abstract}
Seasonal meridional ocean temperature fluxes were computed in a regional study of the eastern North Atlantic Ocean east of $30^{\circ} 30^{\prime} \mathrm{W}$ between $12^{\circ} 30^{\prime} \mathrm{N}$ and $39^{\circ} 30^{\prime} \mathrm{N}$ for the upper $1500 \mathrm{~m}$ of the ocean. Historical oceanographic and meteorological measurements are the data base for the direct method of computing temperature fluxes. Seasonal changes in temperature fluxes caused by the seasonality of Ekman transport and geostrophic transport are strongly dependent on latitude. Between $19 \mathrm{~N}$ and $25 \mathrm{~N}$ the meridional temperature flux shows low seasonality. In this area the permanent subtropical gyre and the stable trade-winds result in low seasonal changes. North of $25 \mathrm{~N}$ the Ekman transport shows large seasonal variations. The latitude of the transition of southward Ekman temperature flux to northward Ekman temperature flux is located at $28 \mathrm{~N}$ in winter. In summer it is found at $38 \mathrm{~N}$. The seasonal variability of the meridional temperature fluxes in the subtropics north of $25 \mathrm{~N}$ is influenced by this annual cycle in Ekman transport, as well as by the southward displacement in summer and the northward movement of the Azores Current in winter. The tropical eastern Atlantic Ocean shows seasonal changes both in the geostrophic and Ekman transports. South of $17 \mathrm{~N}$ the total temperature flux is always to the north. The largest meridional temperature fluxes, with more than $0.7 \mathrm{PW}$, are found in fall at $12^{\circ} 30^{\prime} \mathrm{N}$ directed northward, and in winter at $33^{\circ} 30^{\prime} \mathrm{N}$ to the south. In general the subtropical eastern North Atlantic Ocean transports heat to the south all the year round, while in the tropics heat is transported to the north. The seasonality in the eastern Atlantic Ocean is found to be different from seasonal variations in global investigations. The seasonal heat budget computations show a heat gain in the ocean in the area investigated from April to September and a heat loss from October to March. Over the whole year the eastern North Atlantic gains about 0.09 PW from the atmosphere.
\end{abstract}

\section{Introduction}

The ocean can affect climate either by in situ storage and release of heat or by transport of heat from the tropics to the polar regions. Knowledge of the heat transport in the ocean is important for estimating the influence of the ocean on overall heat transport of the earth and for the understanding of the climatic system. Although several investigations have compared the oceanic and atmospheric components of heat

1. Institut für Meereskunde, Universität Kiel, Düsternbrooker Weg 20, 2300 Kiel, Federal Republic of Germany.

2. Present address: Alfred-Wegener-Institut für Polar- und Meeresforschung, 2850 Bremerhaven, Federal Republic of Germany. 
transport, the influence of the ocean on overall heat transport is still not completely understood.

The classical indirect method has been to consider air-sea interaction: one computes the difference between heat gain and heat loss at the sea surface and the temporal changes of heat storage in the water column (e.g. Lamb and Bunker, 1982; Hastenrath, 1982). The other indirect method uses incoming and outgoing atmospheric radiation and atmospheric heat transport to derive oceanic heat transport (Vonder Haar and Oort, 1973).

For the direct method of calculating ocean heat transport, the velocity distribution in the ocean must be known. The meridional heat flux, $H$, is given as

$$
H=\iint \rho C_{p} \theta v d z d x
$$

where the integration is carried out over depth and longitude (Hall and Bryden, 1982). $\rho$ is the density of sea water, $C_{p}$ is the specific heat capacity of sea-water at constant pressure and is assumed to be constant, $\theta$ is the potential temperature, $v$ is the north-south component of the absolute velocity, $z$ is depth and $x$ is the longitudinal variable. For a section where mass is not conserved, $H$ represents the temperature flux. The temperature flux depends on the temperature scale and is here always calculated in ${ }^{\circ} \mathrm{C}$.

One interesting aspect of studies by Oort and Vonder Haar (1976) and Carissimo et al. (1985) is the very large seasonality in their oceanic heat transports. Numerical models were used to estimate seasonal differences for the heat balance (Bryan, 1982; Sarmiento, 1986), but oceanic observations are too sparse in many regions of the oceans to compute the seasonality in heat transport by the direct method. Merle and Arnault (1985) observed seasonal variability of dynamic height from XBT data in the tropical Atlantic, which could be coupled with variations in heat transport. In an earlier investigation, Stramma and Isemer (1986) computed the latitudinal variation of the annual mean temperature fluxes in the subtropical eastern North Atlantic Ocean. A comparison with CTD sections from the winter half-year showed the possibility of a seasonal signal.

In this paper we compute the change in temperature flux at different latitudes for spring (here April through to June), summer (July through to September), fall (October through to December) and winter (January through to March) in the eastern North Atlantic Ocean in order to investigate the importance of a seasonal cycle in the eastern part of the subtropical gyre, and to compute the seasonal cycle of heat storage.

\section{The data set}

The oceanographic data were taken from an edited data set prepared from historical hydrographic data obtained from the eastern North Atlantic Ocean archived at the 
World Oceanographic Data Center (WODC) A in 1980. Stations with dubious data showing spikes or systematic deviations were rejected (Siedler and Stramma, 1983). This data set was augmented by CTD data of Meteor cruises in March and April 1982 (Stramma, 1984a) and April 1981 (Thiele et al., 1986), and data from two of the beta-triangle cruises (Armi and Stommel, 1983) made with RV Atlantis in October 1979 and August 1981 . Subsets in $3 \times 3^{\circ}$ squares were used to compute mean profiles for the periods January through to March, April through to June, July through to September, and October through to December. From all the single profiles used to obtain one mean profile the mean position within the $3 \times 3^{\circ}$ square was computed.

For our study we needed climatological averages of sea surface temperature, wind stress and net air-sea heat flux. We used a meteorological data set which is based on selected historical ship observations of the voluntary observing fleet (V.O.F.). This data set was originally prepared by Bunker (1976). He calculated long-term monthly averages for irregularly shaped areas in the North Atlantic Ocean for the period 1941 to 1972. Using a local, two-dimensional quadratic polynomial method, Isemer and Hasse (1985) interpolated these data onto a regular $1^{\circ}$ grid net. From these interpolated data we extracted monthly fields of sea surface temperature.

Bunker (1976) applied the bulk aerodynamic equation for his wind stress computations. He used drag coefficients depending on wind speed and stability and calculated the wind stress for each individual ship observation and then averaged the individual wind stress results. Thus, correlations between meteorological parameters are preserved. The drag coefficients which Bunker (1976) used were estimated from the literature published up to that time. Since then, a number of well-performed open ocean measurements of turbulent momentum fluxes, especially under long fetch conditions, have been carried out at various sites in the World Oceans. A comparison of a collection of these experimental results (e.g. Hasse et al., 1978; Smith, 1980; Large and Pond, 1981) showed Bunker's coefficients to be too high by an average $21 \%$ (Isemer and Hasse, 1987, see also Smith and Dobson, 1984). However, it is known that the official Beaufort equivalent scale of the World Meterological Organization (WMO), which Bunker used, produces too low wind speeds in the range of one to eight Beaufort (see e.g. WMO, 1970). If the revised scientific Beaufort scale of Kaufeld (1981) is used instead of the incorrect WMO-scale, climatological monthly averages of scalar wind speed are increased by $1 \mathrm{~m} \mathrm{~s}^{-1}$ in winter in the westwind drift, and by about $2 \mathrm{~m} \mathrm{~s}^{-1}$ in the trade wind region throughout the year (Isemer and Hasse, 1987).

For the wind stress calculation both these effects (lower drag coefficients and higher scalar wind speeds) compensate at least partially, depending on the variable wind climate in the North Atlantic Ocean. Isemer and Hasse (1987) published monthly fields of Bunker's wind stress as well as those of their own recalculation. The latter incorporates the use of Kaufeld's revised Beaufort scale and the revised drag coefficients and uses Bunker's correlations, thus preserving the individual calculation method. For our study we used the latter wind stress data set instead of Bunker's 
original results. The differences to Bunker's results vary regionally and seasonally. In the area of the northeast trades (with maximum wind stress in the investigation area), where zonally averaged stress values exceed $0.14 \mathrm{~Pa}$, the difference reaches $0.03 \mathrm{~Pa}$ ( $=25 \%$ of Bunker's values).

No standard errors for the average wind stress values could be obtained as the original ship observations were not available to us. From the study of Hellerman and Rosenstein (1983) we adopted a maximum standard error for our investigation area of $0.01 \mathrm{~Pa}$ and added another $15 \%$ error to the wind stress because of the uncertainty in the proper choice of a suitable drag coefficient. The calculated total uncertainty for the wind stress at $24^{\circ} 30^{\prime} \mathrm{N}$ was $0.014,0.017,0.025$ and $0.014 \mathrm{~Pa}$ for February, May, August and November, respectively.

\section{Ekman volume transport}

From the monthly $1^{\circ}$ grid data of the east and north components of wind stress $\tau_{x}, \tau_{y}$, the components of the Ekman volume transport, $E_{x}, E_{y}$, were calculated using

$$
\begin{gathered}
E_{x}=\left(f \rho_{w}\right)^{-1} \tau_{y} L_{y} \\
E_{y}=-\left(f \rho_{w}\right)^{-1} \tau_{x} L_{x}
\end{gathered}
$$

$f=2 \Omega \sin \phi$ is the Coriolis parameter, $\phi$ is the latitude, and $\rho_{w}$ is the density of the water in the Ekman layer. We took $\rho_{w}=10^{3} \mathrm{~kg} \mathrm{~m}^{-3}$ as a constant for the Ekman volume transport calculation. $L_{x}=2 \pi R \cos \phi / 360$ and $L_{y}=2 \pi R / 360$ are the zonal and meridional side lengths of each $1^{\circ}$ field ( $R=6370 \mathrm{~km}$ is the earth radius). Hence, $E_{x}$ and $E_{y}$ give the Ekman volume transport (units $\mathrm{m}^{3} \mathrm{~s}^{-1}$ ) through each $1^{\circ}$ field. For the temperature flux calculations the $1^{\circ}$ grid data of Ekman transport and sea surface temperature were averaged over areas $3^{\circ}$ in latitude and longitude, respectively.

It is hardly necessary to state that the annual cycle of the Ekman volume transport is correlated strongly with the surface wind field pattern, modified by the Coriolis parameter; see Figure 1 for monthly maps of the Ekman volume transport. We will shortly discuss some features of the winter and summer months and leave the inspection of the maps relating to the months in the transition seasons spring and fall to the reader without further comment.

The subtropical convergence zone separates the region of prevailing west winds (with Ekman transports directed mainly to the south) from the northeast trade-wind region (covered by Ekman transports mainly directed to the northwest). In the course of its annual cycle the sutropical convergence zone is situated at its southernmost latitude in February (at about $28 \mathrm{~N}$ ) and can easily be identified by conspicuous confluence patterns and also minimum values of the transport (Fig. 1a). Thus, in February (and all winter months) the sutropical northeast Atlantic Ocean shows southward directed Ekman transport in its northern part and north-westward directed transport south of about $28 \mathrm{~N}$. Proceeding southward, the magnitude of the Ekman volume transport grows continuously to more than $0.6 \mathrm{~Sv}$ per $1^{\circ}$ field $\left(1 \mathrm{SV}=10^{6}\right.$ 


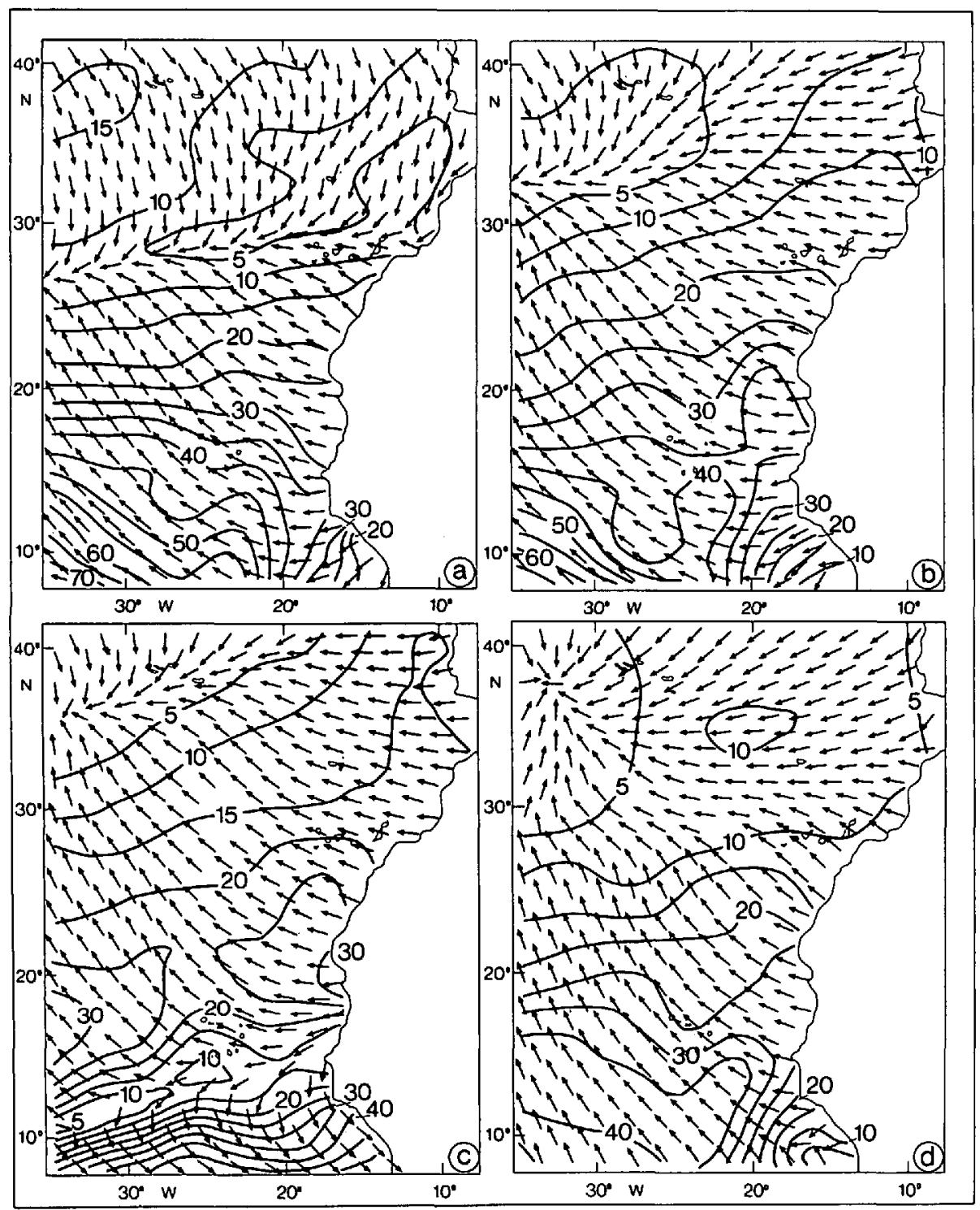

Figure 1. Mean monthly Ekman volume transport in the period 1941 to 1972.The unit vectors show the direction of the transport, they are plotted at every second gridpoint. The isolines show the magnitude of the transport through each $1^{\circ}$ field for (a) February, (b) May, (c) August, and (d) November. The contour interval is $5 \cdot 10^{-2} \mathrm{~Sv}\left(1 \mathrm{~Sv}=10^{6} \mathrm{~m}^{3} \mathrm{~s}^{-1}\right)$.

$\mathrm{m}^{3} \mathrm{~s}^{-1}$ ). It is only close to the African coast south of $12 \mathrm{~N}$ that decreasing Ekman transports indicate the influence of the Intertropical Convergence Zone (ITCZ), which is situated south of the investigation area in winter. During summer, the ITCZ reaches its northernmost position in August and is evident in the investigation area with minimum transport values and conspicuous divergence patterns at about $12 \mathrm{~N}$ (Fig. 
1c). South of the ITCZ the south-eastward directed Ekman transport grows rapidly to nearly $0.5 \mathrm{~Sv}$ per $1^{\circ}$ field at $8 \mathrm{~N}$. Maximum transport values in the northeast trades are only half as big as in February. In contrast to February, the subtropical convergence zone in August is conspicuously visible only west of about $30 \mathrm{~W}$. East of $30 \mathrm{~W}$ one notices a smooth transition in the direction from the trade-wind region to the westwind zone instead of strong confluence patterns with a more abrupt change in transport direction as can be seen in the February map. This annual cycle in the configuration of the Ekman transport in the subtropical convergence zone correlated strongly with the annual cycle in the sea-level air pressure configuration of this area. The winter subtropical atmospheric anticyclone forms a zonally oriented belt (along about $25 \mathrm{~N}$ to $30 \mathrm{~N}$ ), while in summer and fall a meridionally extended high pressure cell, with its center southwest of the Azores, is the dominant feature of the subtropical air pressure configuration in the North Atlantic Ocean (see Isemer and Hasse, 1985, for further details).

The annual meridional migration of the planetary wind system results in three regimes with different behavior in the annual cycle of Ekman volume transport (Fig. 2): a conspicuous annual cycle is evident south of about $19 \mathrm{~N}$ and north of about $25 \mathrm{~N}$, while low seasonality is found between $19 \mathrm{~N}$ and $25 \mathrm{~N}$ with an integrated northward transport component of 2 to $3 \mathrm{~Sv}$ (Fig. 2). This latter area is the permanent trade-wind region. The north-south displacement of the zero meridional transport line between $27 \mathrm{~N}$ in February and nearly $40 \mathrm{~N}$ in July and August reflects the north-south migration of the subtropical convergence zone (or transition region between trades and prevailing westerlies). Integrated southward transport of more than $2 \mathrm{~Sv}$ is found north of $35 \mathrm{~N}$ in winter and south of $10 \mathrm{~N}$ from July through to September. The change in the sign of the meridional Ekman transport component between June/July and September/October is caused by the migration of the ITCZ, the meridional transport is directed to the south, south of the ITCZ (see also Fig. 1c). The annual range of the meridional Ekman transport at $8 \mathrm{~N}$ exceeds $11 \mathrm{~Sv}$ : in December $6 \mathrm{~Sv}$ are transported to the north while in August nearly 5.5 Sv are transported to the south.

\section{Geostrophic transports}

In geostrophic computations using the density distribution, there is always the problem of transferring relative to absolute velocity. Although different methods exist, the problem of computing absolute velocities has not yet been solved. It would be unrealistic to expect that a permanent surface exists wherein the velocities are zero. But one can identify a low-velocity layer, which, when used as an integration reference, yields reasonable, accurate transport. We call this layer here the level of no motion. Stramma (1984b) determined a level of no motion in the subtropical easiern North Atlantic Ocean using yearly mean profiles for $3 \times 3^{\circ}$ squares. He combined information on the advection of water masses with a conservation of mass scheme first used by Fiadeiro and Veronis (1982). The chosen reference depth (level of no motion) is 


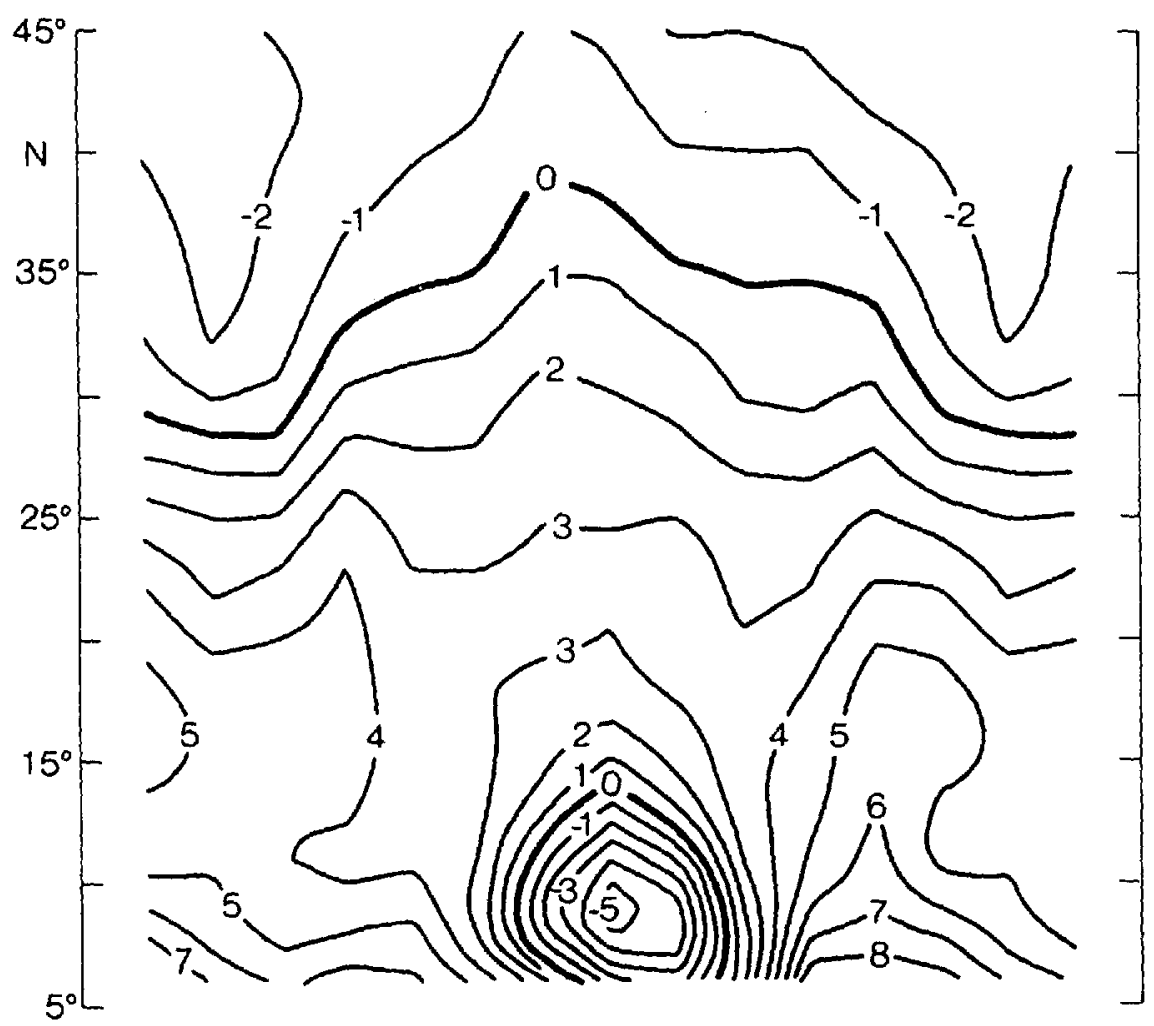

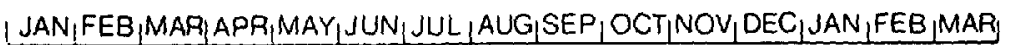

Figure 2. Meridional component of the Ekman volume transport, $E_{y}$, in the subtropical North Atlantic Ocean east of $35 \mathrm{~W}$ as a function of latitude and months. The contour interval is $10^{6} \mathrm{~m}^{3} \mathrm{~s}^{-1} . E_{y}$ was integrated for each $1^{\circ}$ strip between $35 \mathrm{~W}$ and the African and European coasts, respectively. Positive values indicate transport to the north.

located at $1500 \mathrm{~m}$ in the tropics and climbs to $1200 \mathrm{~m}$ in the subtropics (Fig. 6 of Stramma, 1984b). With this given reference depth, the absolute transport can be computed. Stramma and Isemer (1986) used this reference depth to compute the absolute transport. Investigations of the seasonal data sets showed no seasonal influence on the level of no motion. We believe that this depth is too deep for a seasonal signal and therefore use the same reference depth for the seasonal transport computations here.

Figure 3a-d present the geostrophic transport in the upper $1500 \mathrm{~m}$ of the subtropical eastern North Atlantic Ocean for January through to March (3a), April through to June (3b), July through to September (3c) and October through to December (3d), 


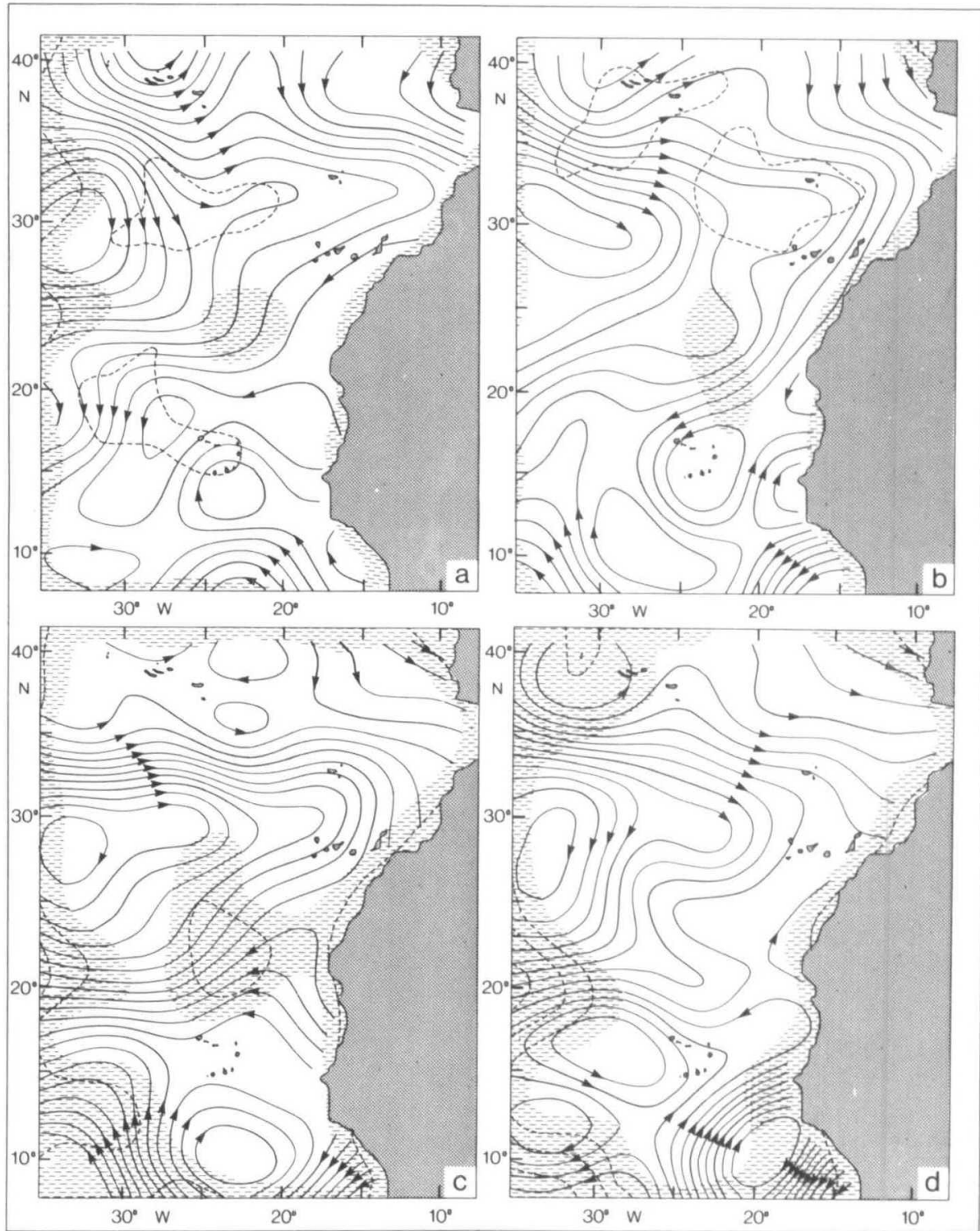

Figure 3. Integrated volume transport ( 0 to $1500 \mathrm{~m}$ ) from mean density profiles for (a) January through March, (b) April through June, (c) July through September and (d) October through December. Each flow line represents $10^{6} \mathrm{~m}^{3} \mathrm{~s}^{-1}$. In addition the error field is shown with dashed lines in $0.5 \times 10^{6} \mathrm{~m}^{3} \mathrm{~s}^{-1}$ steps relative to the $1.5 \times 10^{6} \mathrm{~m}^{3} \mathrm{~s}^{-1}$ error field given by the transfer from blank to shaded areas. 
computed from the seasonal mean profiles. The contours were prepared and smoothed with an objective analysis scheme. As the correlation scale was not known, a value of $500 \mathrm{~km}$ was chosen arbitrarily, which is about 1.4 times the length between the mean profiles and is a scale larger than the eddy scale. The error variance was chosen to be $30 \%$ of the total variance. Some tests were made with different correlation scales and error variances but the changes in the flow field were unimportant. The error field computed with the objective analysis scheme shows error values higher than $1.5 \times 10^{6}$ $\mathrm{m}^{3} \mathrm{~s}^{-1}$ as the shaded areas in Figure 3. Large areas with error values exceeding $1.5 \times$ $10^{6} \mathrm{~m}^{3} \mathrm{~s}^{-1}$ reflect some $3 \times 3^{\circ}$ squares without a profile for this season. This is the case mainly at the western boundary, the southern boundary and in a region between the Canary Islands and the Cape Verde Islands.

The subtropical gyre is present in all 4 seasons with a transport of the order of $10 \times$ $10^{6} \mathrm{~m}^{3} \mathrm{~s}^{-1}$ east of $35 \mathrm{~W}$ between 0 and $1500 \mathrm{~m}$ depth. The main inflow enters south of the Azores as a relatively narrow current, the Azores Current, turns southward and then widens. The Portugal Current is always weak compared to the Azores Current. Although the subtropical gyre transports nearly the same amount of water in all seasons, the location of the current changes. From April through to September the southward transport near the African coast is larger than that from October through to March, when the subtropical gyre is stronger west of the Canary Islands.

One important feature is the southward displacement of the Azores Current in summer (Fig. 3c), when the entire Azores Current is located south of $35 \mathrm{~N}$. In winter (Fig. 3a), the Azores Current is found just south of the Azores. At the southern part of the investigation area the data are sparse and geostrophic computations are more sensitive to data variations. Therefore the tropical transports shown in Figures 3a-d must be regarded with some caution.

\section{Temperature fluxes}

The total temperature flux of the eastern North Atlantic Ocean for the four seasons is computed from the temperature flux due to Ekman transport and the latter due to geostrophic transport using Eq. (1). Because the data come from two sources, it is convenient to rewrite (1) as

$$
H=\iint \rho C_{p} \theta v_{\text {Ekman }} d z d x+\iint \rho C_{p} \theta v_{\text {geostrophic }} d z d x
$$

The Ekman volume transport is computed from Eq. (3). Following Hall and Bryden (1982), an Ekman depth of $50 \mathrm{~m}$ was assumed and a weighted average of temperature at the surface and $50 \mathrm{~m}, \bar{\theta}=\left(2 \theta_{0 \mathrm{~m}}+\theta_{50 \mathrm{~m}}\right) / 3$, was used to calculate the Ekman temperature flux as

$$
H_{\text {Ekman }}=E_{y} \bar{\theta} C_{p} \rho .
$$

The sea surface temperature (SST) was taken from the V.F.O. data set because of the greater number of observations available compared to the data from oceanographic 
CTD stations. The temperature at $50 \mathrm{~m}$ depth was taken from the seasonal mean profiles. The density was taken at $20 \mathrm{~m}$ depth. The results depend only slightly on density; therefore the error due to the chosen density is negligible. For each $3^{\circ}$-square the Ekman temperature flux was computed for the mid-season month (e.g. February for winter) and zonally summed. The geostrophic temperature flux was computed from the geostrophic velocity of the seasonal mean profiles without the interpolation and smoothing of the objective analysis scheme used to prepare the Figures 3a-d. The mean seasonal temperature fluxes are given for the top $1500 \mathrm{~m}$ of the ocean. This depth includes the warm water sphere and the layer of the Mediterranean water spreading in the Atlantic Ocean.

The major source of error is the geostrophic transport at greater depths (Stramma and Isemer, 1986) because the error increases linearly with depth (Fomin, 1964). The geostrophic velocities are small in the deep ocean, and a poor choice of the level of no motion has a large influence on water transport. In the area investigated here, Stramma and Isemer (1986) presented the geostrophic temperature flux for 0 to $1000 \mathrm{~m}$ depth and from the ocean surface to the bottom. The results of the upper $1000 \mathrm{~m}$ were also present in the surface to bottom flux but with large variations because of the influence of errors. By dividing the data of all $3 \times 3^{\circ}$ squares into four seasons, many seasonal profiles have no data in the deep ocean. Therefore, we will compute only the geostrophic temperature flux for the upper $1500 \mathrm{~m}$ of the ocean. As the main temperature fluxes are found in the warm water sphere, where the computation errors are small (Stramma and Isemer, 1986) the large seasonal signal will be restricted to the upper ocean. This leads us to the assumption, that the chosen area between 0 and $1500 \mathrm{~m}$ depth is a good approximation for the computation of the seasonality. With a general circulation model Philander and Pacanowski (1986) found that the heat flux in the deep ocean is so small that variations in temperature or velocity of the deep ocean are unlikely to have a significant effect on the heat transport. Assuming isopycnal motion, a density surface should be used as the lower boundary, but at $1500 \mathrm{~m}$ depth the differences in the heat flux computations are expected to be small because the velocities at that depth are low and the slopes of the isopycnal surfaces are small.

As the seasonal geostrophic transport computations on the western and southern part of the investigation area are poor, the area 32 to $35 \mathrm{~W}$ and 8 to $11 \mathrm{~N}$ has not been used in this investigation. Eight of these $3 \times 3^{\circ}$ squares had no profile in one of the seasons and the results of this investigation would be influenced too much by errors. By. using just the area north of $11 \mathrm{~N}$ and east of $32 \mathrm{~W}$ only two areas had no profile for one season at the western end of a section used to compute the meridional geostrophic temperature flux. These are fall at $18.5 \mathrm{~N}$ and summer at $12.5 \mathrm{~N}$. In these two cases the temperature fluxes were computed between the coast and $27.5 \mathrm{~W}$, and the temperature fluxes between $27.5 \mathrm{~W}$ and $30.5 \mathrm{~W}$ were computed from the geostrophic transport by means of linear interpolation between the two profiles north and south of the missing profile. 


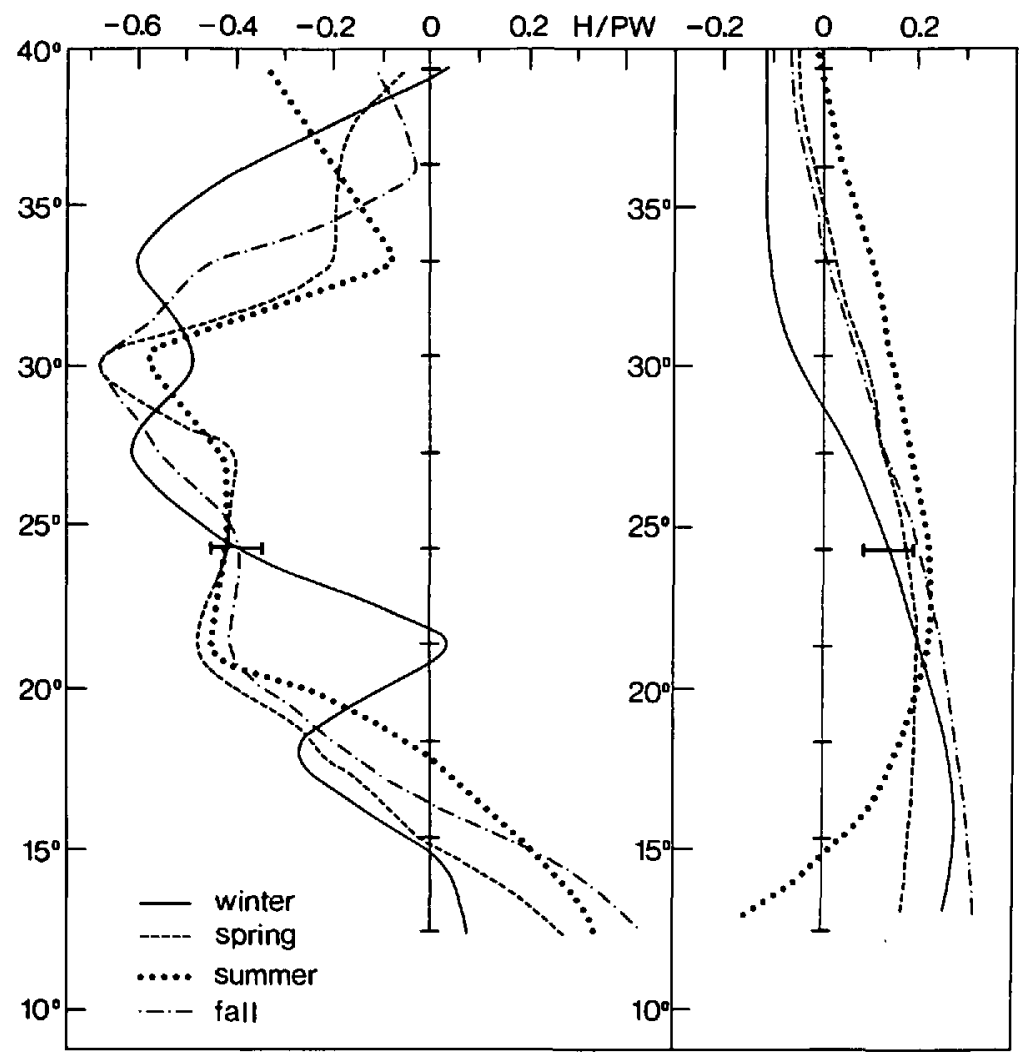

Figure 4. The components of meridional temperature fluxes between $30^{\circ} 30^{\prime} \mathrm{W}$ and the European and African coasts for the 4 seasons. The left side is the geostrophic component between 0 and $1500 \mathrm{~m}$ depth. The right side is the Ekman component. Positive flux is to the north, negative to the south $\left(1 \mathrm{PW}=10^{15} \mathrm{~W}\right)$. The latitudes where the fluxes were computed are marked on the ordinate at $\mathbf{O P W}$.

\section{Results}

The meridional temperature fluxes are presented for the area from the African and European coasts to $30^{\circ} 30^{\prime} \mathrm{W}$ and between $12^{\circ} 30^{\prime} \mathrm{N}$ and $39^{\circ} 30^{\prime} \mathrm{N}$. Figure 4 (left side) shows the seasonal geostrophic temperature fluxes between the sea surface and $1500 \mathrm{~m}$ depth. The maximum southward temperature flux is found at about $30 \mathrm{~N}$. At this latitude the center of the subtropical gyre in the eastern North Atlantic Ocean is to be found. Between $30 \mathrm{~N}$ and $20 \mathrm{~N}$ there is only little variation in the geostrophic temperature flux. The geostrophic transport shows little variability for the seasons and the geostrophic temperature flux is dominated in this area by a permanent ocean current with low seasonality. Only the curve for winter shows a large deviation at $21^{\circ} 30^{\prime} \mathrm{N}$ with a small northward flux. Figure 3a shows that in winter the southward transport typically observed at $21^{\circ} 30^{\prime} \mathrm{N}$ is just west of $30 \mathrm{~W}$ and therefore not present in 
the geostrophic temperature flux computation. As the hydrographic data are sparse in the area 20 to $25 \mathrm{~N}$ we expect this deviation to be a result of bad historic profiles and the choice of the western boundary of the temperature flux computation and not to be a seasonal signal. The small seasonal variations between 30 and $20 \mathrm{~N}$ (Fig. 4) are of the order of the signal of noise from the data and the error from the choice of the reference depth (Stramma and Isemer, 1986). Therefore it is not useful to search for small seasonal signals in this area.

South of $15 \mathrm{~N}$ the meridional geostrophic temperature flux is directed to the north. The largest northward flux in the tropics of 0.3 to $0.4 \mathrm{PW}$ is found in summer and fall. From ship drift data, Richardson and Walsh (1986) computed the North Equatorial Countercurrent to be strong in the North Atlantic Ocean from July through to December. This countercurrent transports warm equatorial water to the tropical northeast Atlantic Ocean and the North Equatorial Current shifts to the north (Fig. 4 of Richardson and Walsh, 1986). This is the reason for the large northward geostrophic temperature flux in summer and fall and the explanation for the northward shift of the latitude of zero crossing in geostrophic temperature flux in summer and fall. Although the transport fields produced with the objective analysis in Figure 3 look disturbed and noisy, the geostrophic temperature flux computations from the original seasonal profiles show clearly the seasonal movement of the zero crossing between $15 \mathrm{~N}$ and $18 \mathrm{~N}$.

The southward shift of the Azores Current in summer and also in spring can be seen from the low geostrophic temperature flux values for these two seasons at $33^{\circ} 30^{\prime} \mathrm{N}$. In fall and winter the southward flux is more than twice as large at this latitude. The variation at $39^{\circ} 30^{\prime} \mathrm{N}$ is mainly due to the choice of the western end of the section at $30^{\circ} 30^{\prime} \mathrm{W}$. The hydrographic data favor a circulation of some hundred kilometers near the Azores, which might be included in the flux computations like in summer (Fig. 3c) or contain only one component like in winter (Fig. 3a) which leads to an apparent northward flux.

Hall and Bryden (1982) computed a southward temperature flux of $1.58 \mathrm{PW}$ with a geostrophic volume transport of $29.5 \times 10^{6} \mathrm{~m}^{3} \mathrm{~s}^{-1}$ on a transatlantic section at $24^{\circ} 30^{\prime} \mathrm{N}$. Here we find a temperature flux of $0.4 \mathrm{PW}$ at this latitude east of $30^{\circ} 30^{\prime} \mathrm{W}$ in all seasons with a transport of about $7 \times 10^{6} \mathrm{~m}^{3} \mathrm{~s}^{-1}$. Therefore east of $30^{\circ} 30^{\prime} \mathrm{W}$ a quarter of the southward geostrophic transport and of the geostrophic temperature flux of the Atlantic Ocean takes place.

The meridional Ekman temperature fluxes east of $30^{\circ} 30^{\prime} \mathrm{W}$ are shown in Figure 4 (right side). Large seasonal variations are found in the tropics and north of $27 \mathrm{~N}$. Only low seasonality is observed at $21^{\circ} 30^{\prime} \mathrm{N}$, in the area of the stable trade-winds. Most obvious is the change from northward to southward Ekman temperature flux in summer at $12^{\circ} 30^{\prime} \mathrm{N}$. This is the influence of the intertropical convergence zone which moves to the north in summer. In the subtropics the latitude of transition of the southward Ekman temperature flux to the northward Ekman temperature flux has a 
large seasonal signal. The zero-crossing is seen at $38 \mathrm{~N}$ in summer and $28 \mathrm{~N}$ in winter. The curves of the meridional Ekman temperature fluxes for spring and fall in the subtropics are almost identical. These two curves separate in the tropics, where in fall the largest northward Ekman temperature flux is to be found. The meridional geostrophic and Ekman temperature fluxes show seasonal variations, which are not necessarily correlated. For example the Ekman temperature flux in the tropics in summer is weak compared to the other seasons, while the geostrophic temperature flux is quite high in summer. Therefore the seasonality of geostrophic and Ekman transports and the temperature fluxes related to them have to be investigated separately.

To estimate the error bars in the Ekman temperature fluxes, the changes in the Ekman transports from the calculated uncertainty in wind stress at $24^{\circ} 30^{\prime} \mathrm{N}$ of $0.025 \mathrm{~Pa}$ or less are computed to be $20 \%$. Although the errors due to the density and the weighted average of temperature in the Ekman layer are small, we add $5 \%$ for these effects. This leads to an uncertainty of $50 \times 10^{12} \mathrm{~W}$ at $24^{\circ} 30^{\prime} \mathrm{N}$. We include this error bar for the Ekman temperature flux in Figure 4 (right side) on the winter curve. To investigate the error bars for the geostrophic component we carried out computations like Stramma and Isemer (1986) at $24^{\circ} 30^{\prime} \mathrm{N}$, but here for the $0-1500 \mathrm{~m}$ temperature fluxes east of $30^{\circ} 30^{\prime} \mathrm{W}$. Following Fiadeiro and Veronis (1982), typical instrument precisions of $0.02^{\circ} \mathrm{C}, 0.005$ and $0.5 \%$ for temperature, salinity and depth, respectively, were multiplied by randomly selected numbers between -1 and +1 and then added to the mean profiles. The altered profiles were then used to compute the geostrophic temperature fluxes. Three sets of data with noise were produced. The fluxes of these data sets differ relative to the section without noise by $41 \times 10^{12} \mathrm{~W}$ or less. Changing the reference depth (which is between 1230 and $1340 \mathrm{~m}$ in this section) to $1500 \mathrm{~m}$ reduced the flux by $11 \times 10^{12} \mathrm{~W}$ and to unrealistic $1700 \mathrm{~m}$ by $21 \times 10^{12} \mathrm{~W}$. Thus the error due to the reference depth and data noise is of about $50 \times 10^{12} \mathrm{~W}$ at $24^{\circ} 30^{\prime} \mathrm{N}$. We included this error bar in the geostrophic flux in Figure 4 at the winter curve. We expect the error bars for both components to be about the same for all seasons and latitudes.

\section{Discussion}

Contrary to heat flux computations with annual mean data, here we can investigate changes in the meridional temperature fluxes at different latitudes for the four seasons. This investigation has dealt with only a part of the Atlantic Ocean, but we are able to present the seasonality at different latitudes. Figure 5 shows the total (Ekman plus geostrophic) meridional temperature fluxes in the eastern North Atlantic Ocean. In general the temperature fluxes are dominated by the geostrophic fluxes. Between $19 \mathrm{~N}$ and $25 \mathrm{~N}$ the total meridional temperature flux shows low seasonality (with the assumption that the winter geostrophic transport at $21^{\circ} 30^{\prime} \mathrm{N}$ is not correct). This is the area of the southern part of the subtropical gyre and of the permanent trade winds. The 


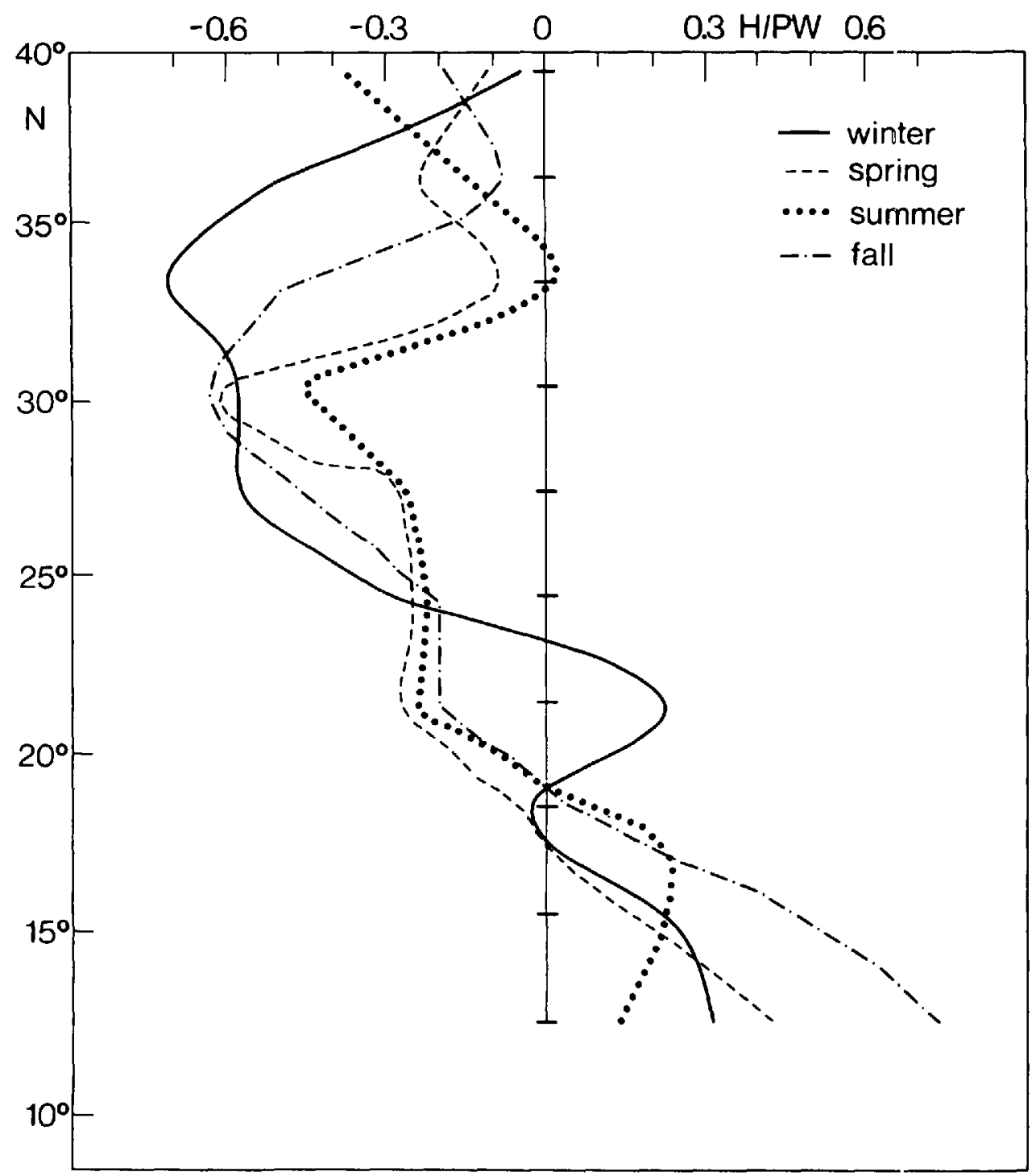

Figure 5. Total meridional temperature fluxes between $30^{\circ} 30^{\prime} \mathrm{W}$ and the European and African coasts from the surface to $1500 \mathrm{~m}$ depth. Positive flux is to the north.

northern part of the subtropical gyre has low seasonal variability of the geostrophic transport, but between $25 \mathrm{~N}$ and $31 \mathrm{~N}$ the total temperature flux shows some variation due to the seasonal changes in Ekman transport. North of $31 \mathrm{~N}$ and south of $19 \mathrm{~N}$ both geostrophic and Ekman transport influence the seasonality of temperature flux. South of $17 \mathrm{~N}$ the total temperature flux is always to the north, but weak in summer at $12^{\circ} 30^{\prime} \mathrm{N}$, where the Ekman transport is to the south. The largest temperature fluxes 
with more than $0.7 \mathrm{PW}$ are found in fall at $12^{\circ} 30^{\prime} \mathrm{N}$ to the north and in winter at $33^{\circ} 30^{\prime} \mathrm{N}$ to the south. In general the subtropical eastern North Atlantic Ocean transports heat to the south all year round, while in the tropics heat is transported to the north. The seasonality in the eastern North Atlantic Ocean is superimposed on this annual mean configuration. In the North Atlantic Ocean the western boundary current transports more heat energy to the north than the recirculation transports to the south. Therefore our findings of a permanent southward flux in the subtropics are not inconsistent with global heat flux computations showing northward oceanic flux at these latitudes.

The strong southward heat flux found by Carissimo et al. (1985) and Oort and Vonder Haar (1976) in summer near the equator might be indicated in our results by the lowest northward temperature flux at $12^{\circ} 30^{\prime} \mathrm{N}$, but their weak northward transport in the subtropics in summer compared to the other seasons is not present in our study. The only data analysis of seasonal heat transport estimates that we are aware of for the Atlantic Ocean is that of Lamb (1981) using an indirect method. His findings of possible southward heat transport in the North Atlantic Ocean in November and December are not present in our results, where the meridional temperature flux in fall does not significantly differ from the other seasons.

We intend to compute the seasonal cycle of oceanic temperature fluxes and oceanic heat storage. It is interesting to investigate whether the residuum of both agrees or disagrees with independent estimates of the net heat flux through the air-sea interface in the eastern North Atlantic Ocean. The net air-sea heat flux may be computed as the sum of net shortwave radiation, net longwave radiation and the turbulent fluxes of latent and sensible heat. We extracted air-sea heat flux data, again based on V.O.F. observations from the period 1941 to 1972, from the compilations of Isemer and Hasse (1987). They discussed and used revised parameterizations for the radiation and turbulent fluxes which differ in several aspects from those used by Bunker (1976). We calculated the area averages of the four components and the net air-sea heat flux $Q_{\text {TOT }}$ for the eastern North Atlantic Ocean (Table 1).

In the course of the year the sign of $Q_{\text {TOT }}$ changes: the average for the fall season is nearly $-70 \mathrm{~W} \mathrm{~m}^{-2}$ while in summer the ocean gains about $80 \mathrm{~W} \mathrm{~m}^{-2}$. Note, that these large-scale averages hide quite heterogeneous regional structures of $Q_{\text {Tот }}$ (see Isemer and Hasse, 1987, for details): in the upwelling regions near the African coast the net air-sea heat flux is directed into the ocean in nearly every month, except in December, and exceeds $200 \mathrm{~W} \mathrm{~m}^{-2}$ in June. West of about $20 \mathrm{~W}$ heat gain reaches $100 \mathrm{~W} \mathrm{~m}^{-2}$ north of $25 \mathrm{~N}$ in June, while heat loss exceeds $-125 \mathrm{~W} \mathrm{~m}^{-2}$ in January. The annual variation of $Q_{\text {Tот }}$ grows from about $150 \mathrm{~W} \mathrm{~m}^{-2}$ at $12 \mathrm{~N}$ to more than $250 \mathrm{~W} \mathrm{~m}^{-2}$ at $40 \mathrm{~N}$. The uncertainty of $Q_{\text {Tот }}$ is between $28 \mathrm{~W} \mathrm{~m}^{-2}$ in summer at $35 \mathrm{~N}^{2}$ and $32 \mathrm{~W} \mathrm{~m}^{-2}$ in winter at $15 \mathrm{~N}$. Hence, the sign of the annual avarage value of about $16 \mathrm{~W} \mathrm{~m}^{-2}$ (Table 1) has to be seen with caution.

To compute the seasonal heat budget from the temperature fluxes, we had to close 
Table 1. Energy budget at the sea surface of the eastern North Atlantic Ocean $(12 \mathrm{~N}-40 \mathrm{~N}$, east of 31 W) extracted from Isemer and Hasse (1987). Positive values indicate heat input into the ocean. Seasonal and annual averages for the net shortwave radiation $Q$, net longwave radiation $I R$, the turbulent fluxes of latent and sensible heat, $L E$ and $H$, and the net air sea heat flux $\mathrm{Q}_{\text {Tor }}$ are given in $\mathrm{W} \mathrm{m}^{-2}$ (upper number) and in $10^{12} \mathrm{~W}$ (lower number). The total investigated area covers $5.7 \times 10^{12} \mathrm{~m}^{2}$.

$\begin{array}{lcclccc} & Q & I R & L E & H & & Q_{\text {Tor }} \\ \text { Jan-March } & 162.4 & -49.4 & -130.9 & -12.2 & = & -30.1 \\ & 926 & -282 & -746 & -69 & - & -171 \\ \text { April-June } & 248.1 & -46.7 & -114.9 & -6.3 & = & 80.2 \\ & 1414 & -265 & -655 & -36 & = & 458 \\ \text { July-Sept } & 238.7 & -42.3 & -110.1 & -4.9 & = & 81.4 \\ & 1360 & -241 & -628 & -28 & = & 464 \\ \text { Oct-Dec } & 141.9 & -45.5 & -150.3 & -14.7 & = & -68.5 \\ & 809 & -260 & -857 & -84 & - & -392 \\ \text { Year } & 197.8 & -46.0 & -126.6 & -9.5 & - & 15.7 \\ & 1127 & -262 & -721 & -54 & - & 90\end{array}$

our box between $12^{\circ} 30^{\prime} \mathrm{N}$ and $39^{\circ} 30^{\prime} \mathrm{N}$ along $30^{\circ} 30^{\prime} \mathrm{W}$ and at the entrance to the Mediterranean Sea. We computed the geostrophic and Ekman temperature fluxes along $30^{\circ} 30^{\prime} \mathrm{W}$ and at $9^{\circ} 30^{\prime} \mathrm{W}$ at the entrance to the Mediterranean Sea. The total temperature fluxes through the boundaries of the area between 0 and $1500 \mathrm{~m}$ are given in Table 2a. In addition to this the heat storage $Q$

$$
Q=\int A C_{p} \theta \rho d z
$$

with the area $A$ of a $3^{\circ}$-square was computed for each $3^{\circ}$-square over the depth 0 to $1500 \mathrm{~m}$ and then summed for the area investigated. From the difference in heat storage between a season and the previous one divided by the time of three months (Table $2 \mathrm{a}$, D), we find a value which, when subtracted from the seasonal temperature fluxes, should represent the heat transfer between atmosphere and ocean.

In Table $2 b$ the results are presented for the heat budget derived from meteorological data and from the wind stress and hydrographic data. The heat budgets from these two different data sets always show the same direction of heat transfer. From April to September the ocean gains energy from the atmosphere, while from October to March the atmosphere gains energy from the ocean. For the entire year there is a net heat gain for the area investigated of $90 \times 10^{12} \mathrm{~W}$ from the meteorological data and $67 \times 10^{12} \mathrm{~W}$ from the temperature flux computations. The seasonal computations from these two different data sets differ, except for the period July to September, by a factor of less than two. From the different error estimates given before, a factor of two is even better than expected. The comparison in Table $2 \mathrm{~b}$ shows that the seasonal heat budget can be estimated, but also shows the limitation of such computations, which requires much smaller error bars to obtain identical results. 
Table 2. (a) Temperature fluxes and heat storage in the area $12^{\circ} 30^{\prime} \mathrm{N}$ to $39^{\circ} 30^{\prime} \mathrm{N}$ east of $30^{\circ} 30^{\prime} \mathrm{W}$ with (A) the total temperature fluxes through the boundaries of the area from 0 to $1500 \mathrm{~m}$ depth (positive values indicate a flux into the area); (B) the heat storage of the top $1500 \mathrm{~m}$ of the area; (C) the difference in heat storage relative to the previous season with positive values for an increase of the heat storage and (D) the value of $C$ divided by the time of three months.

$\begin{array}{lcccc} & \text { (A) }\left[\cdot 10^{12} \mathrm{~W}\right] & \text { (B) }\left[\cdot 10^{20} \mathrm{Ws}\right] & \text { (C) }\left[\cdot 10^{20} \mathrm{Ws}\right] & \text { (D) }\left[\cdot 10^{12} \mathrm{~W}\right] \\ \text { Jan-March } & -370 & 3093 & -40 & -507 \\ \text { April-June } & 114 & 3112 & 19 & 241 \\ \text { July-Sept } & -546 & 3128 & 16 & 203 \\ \text { Oct-Dec } & 534 & 3133 & 5 & 63\end{array}$

(b) The seasonal heat budget for the area investigated (positive values indicate heat transfer from the atmosphere to the ocean) from the meteorological data (Table 1) in (A) and in (B) from the difference between the temperature fluxes through the boundaries and the change in heat storage (Table $2 a$ ).

$\begin{array}{lrc} & \text { (A) }\left[\cdot 10^{12} \mathrm{~W}\right] & (B)\left[\cdot 10^{12} \mathrm{~W}\right] \\ \text { Jan-March } & -171 & -137 \\ \text { April-June } & 458 & 127 \\ \text { July-Sept } & 464 & 749 \\ \text { Oct-Dec } & -392 & -471 \\ \text { Year } & 90 & 67\end{array}$

In the regional study of the eastern North Atlantic Ocean seasonal variability of temperature fluxes is shown to be strongly dependent on the latitude. Important is the annual variability or stability of both the ocean currents and the wind fields. Their changes have to be included in seasonal investigations. The seasonality in our regional study is found to be different from the seasonal variations found in global investigations. This investigation gives at least an insight into seasonal changes in meridional temperature fluxes at different latitudes and shows the usefulness of the direct method for seasonal investigations. The method is restricted by the oceanographic data base, which is too small for seasonal investigations in many areas of the World Ocean. Heat flux computations with the direct method will be an important part of the World Ocean Circulation Experiment (WOCE). Using single hydrographic sections for heat transport computations with the direct method requires careful investigations of the local seasonality.

This paper might also serve as a documentation of what the present data are capable of supporting. The use of historic data for temperature flux computations requires careful investigation of data quality and the rejection of bad data. In the central and eastern parts of the oceans it is desirable to have good deep hydrographic profiles for all seasons in each $3 \times 3^{\circ}$-square and deep profiles near the eastern boundary to include the fluxes near the coast. For heat flux computations from hydrographic ship sections, as 
scheduled for the WOCE experiment, the error of $50 \times 10^{12} \mathrm{~W}$ found here at $24^{\circ} 30^{\prime} \mathrm{W}$ can be reduced by searching for a reasonable reference depth as well as using calibrated high-quality instruments.

We did not investigate long-term changes or interannual variability in this study. For example Servain and Legler (1986) observed an increase of the trade-winds in the Atlantic Ocean between the 1960s and the 1970s. Because of the lack of direct measurements, the influence of these changes could only be investigated by numerical models or by special local observation experiments.

Acknowledgments. This work was supported by the Deutsche Forschungsgemeinschaft, Bonn, F.R.G. (SFB 133). We would like to thank L. Armi (Scripps Institution of Oceanography) for kindly providing us with the tapes of the beta triangle cruises, and the anonymous reviewers for helpful comments on the manuscript.

\section{REFERENCES}

Armi, L. and H. Stommel. 1983. Four views of a portion of the North Atlantic subtropical gyre. J. Phys. Oceanogr., 13, 828-857.

Bunker, A. F. 1976. Computations of surface energy flux and annual air-sea interaction cycles of the North Atlantic Ocean. Mon. Weather Rev., 104, 1122-1140.

Bryan, K. 1982. Seasonal variation in meridional overturning and poleward heat transport in the Atlantic and Pacific Oceans: A model study. J. Mar. Res., 40, (Suppl.), 39-53.

Carissimo, B. C., A. H. Ort and T. H. Vonder Haar. 1985. Estimating the meridional transports in the atmosphere and ocean. J. Phys. Oceanogr., 15, 82-91.

Fiadeiro, M. E. and G. Veronis. 1982. On the determination of absolute velocities in the ocean. J. Mar. Res., 40, (Suppl.), 159-192.

Fomin, L. M. 1964. The Dynamical Method in Oceanography. Elsevier Oceanographic Series, $212 \mathrm{pp}$.

Hall, M. M. and H. L. Bryden. 1982. Direct estimates and mechanisms of ocean heat transport. Deep-Sea Res., 29, 339-359.

Hasse, L., M. Grunewald, J. Wucknitz, M. Dunckel and D. Schriever. 1978. Profile derived turbulent fluxes in the surface layer under disturbed and undisturbed conditions during GATE. Meteor-Forschungsergebnisse B, 13, 24-40.

Hastenrath, S. 1982. On meridional heat transport in the world ocean. J. Phys. Oceanogr., 12, 922-927.

Hellerman, S. and M. Rosenstein. 1983. Normal monthly wind stress over the world ocean with error estimates. J. Phys. Oceanogr., 13, 1093-1104.

Isemer, H.-J. and L. Hasse. 1985. The Bunker Climate Atlas of the North Atlantic Ocean. Volume 1: Observations. Springer-Verlag, Berlin, $218 \mathrm{pp}$.

— 1987. The Bunker Climate Atlas of the North Atlantic Ocean. Volume 2: Air-sea Interactions. Springer-Verlag, Berlin, $252 \mathrm{pp}$.

Kaufeld, L. 1981. The development of a new Beaufort equivalent scale. Meteorologische Rundschau, 34, 17-23.

Lamb, P. J. 1981. Estimate of annual variation of Atlantic Ocean heat transport. Nature, 290. 766-768.

Lamb, P. J. and A. F. Bunker. 1982. The annual march of the heat budget of north and tropical Atlantic Oceans. J. Phys. Oceanogr., 12, 1388-1410. 
Large, W. G. and S. Pond. 1981. Open ocean momentum flux measurements in moderate to strong winds. J. Phys. Oceanogr., 11, 324-336.

Merle, J. and S. Arnault. 1985. Seasonal variability of the surface dynamic topography in the tropical Atlantic Ocean. J. Mar. Res., 43, 267-288.

Oort, A. H. and T. H. Vonder Haar. 1976. On the observed annual cycle in the oceanatmosphere heat balance over the northern hemisphere. J. Phys. Oceanogr., 6, 781-800.

Philander, S. G. H. and R. C. Pacanowski. 1986. The mass and heat budget in a model of the tropical Atlantic Ocean. J. Geophys. Res., 91, 14212-14220.

Richardson, P. L. and D. Walsh. 1986. Mapping climatological seasonal variations of surface currents in the tropical Atlantic using ship drifts. J. Geophys. Res., 91, 10537-10550.

Sarmiento, J. L. 1986. On the north and tropical Atlantic heat balance. J. Geophys. Res., 91 , $11677-11689$.

Servain, J. and D. M. Legler. 1986. Empirical orthogonal function analyses of tropical Atlantic sea surface temperature and wind stress: 1964-1979. J. Geophys. Res., 91, 14181-14191.

Siedler, G. and L. Stramma. 1983. The applicability of the T/S method to geopotential anomaly computations in the Northeast Atlantic. Oceanol. Acta, 6, 167-172.

Smith, S. D. 1980. Wind stress and heat flux over the ocean in gale force winds. J. Phys. Oceanogr., 10, 706-726.

Smith, S. D. and F. Dobson. 1984. The heat budget at ocean weather station bravo. Atmosphere-Ocean, 22, 1-22.

Stramma, L. 1984a. Potential vorticity and volume transport in the eastern North Atlantic from two long CTD sections. Dt. Hydrogr. Z., 37, 147-155.

1984b. Geostrophic transport in the Warm Water Sphere of the eastern subtropical North Atlantic. J. Mar. Res., 42, 537-558.

Stramma, L. and H.-J. Isemer. 1986. Meridional temperature fluxes in the subtropical eastern North Atlantic. Deep-Sea Res., 33, 209-223.

Thiele, G., W. Roether, P. Schlosser, R. Kuntz, G. Siedler and L. Stramma. 1986. Baroclinic flow and transient-tracer fields in the Canary-Cape-Verde Basin. J. Phys. Oceanogr., 16, 814-826.

Vonder Haar, T. H. and A. H. Oort. 1973. New estimate of annual poleward energy transport by northern hemisphere oceans. J. Phys. Oceanogr., 3, 169-172.

WMO. 1970. Reports on marine science affairs. Rep. no. 3. The Beaufort scale of wind force. WMO, Geneva, $22 \mathrm{pp}$.

Received: 23 April, 1987; revised: 25 January, 1988. 